\title{
Morphologic matrix application as a tool to spring on creativity. Results in a design master in the UPV
}

\section{Carlos Manuel Dema Perez ${ }^{\mathrm{a}, \mathrm{b}}$, Carlos Fernández Llatas ${ }^{\mathrm{a}, \mathrm{c}}$, Antonio Martinez-Miñana ${ }^{\mathrm{a}, \mathrm{d}}$, Sofía Estelles-Miguel ${ }^{\mathrm{e}}$}

aTACA-Research-Group, Universitat Politècnica de València, camino de Vera s/n, 46022 Valencia Spain, ${ }^{b}$ cmdema@upv.es, ${ }^{c}$ cfllatas@itaca.upv.es, ${ }^{\text {danmarmi@itaca.upv.es, }}$

eDepartamento de Organización de Empresas (DOE). Universitat Politècnica de València, camino de Vera s/n, 46022 Valencia, Spain, soesmi@omp.upv.es

\begin{abstract}
Some years ago our group had the challenge of collaborating on a design master teaching an optative subject of Technology Management Foundations. The challenge was to develop it in an attractive way capable of interesting really students and generating a motivated behaviour in class. Now, seven years later, it is possible to have a complete landscape of this experience. Designers profile was very different from the profile of mechanical, electric, electronics, chemical, ... engineers we usually had in class, and this reality was a problem at the beginning of first edition when we had to resolve it and to define the basis to thenew master editions. Main tool taken from technological forecasting to apply it as a design tool was Morphology. Our group had applied this methodology since many years ago. First on doctorate courses of "Technology Management" and afterwards on postgraduate courses and masters. On this paper we discuss the experience on a design master where this methodology was applied as a tool for developing new products combining with other techniques for spurring creativity as brain storming, lateral thinking, de Bono's hats, nominal group, etc. Other forecasting methodologies were gap analysis and analogies.

Examples of final works have not been included so it is not possible contacting students to ask for permission in order to include them on the paper.
\end{abstract}

Keywords:, Morphology, designg, forecasting tools. 

$U P V$

\section{Introduction}

Some years ago our group had the challenge of collaborating on a design master teaching an optative subject called "Technology Management Foundations". Challenge was to develop it in an attractive way capable of really interesting students and generating a motivated behaviour in class. Now, seven years later, it is possible to have a complete landscape of this experience. Designers profile was very different from the profile of mechanical, electric, electronics, chemical, ... engineers we usually have in class. On first place only a part of them had a European engineering degree, about $40 \%$ on average. $60 \%$ left was composed by a $50 \%$ of Latin-American designers with different degrees or design titles and a $10 \%$ of students with experience on design but without any title. First year contents and schedule were similar to we usually utilized on class and based on classical texts (Christiansen, 1977) (Tidd, Bessant \& Pavitt, 1960) (Escorsa \& Maspons, 2001) (Makridakis \& Wheelwright. 1990) (Jones \& Twiss, 1980). But after two early sessions, of four hours, we realized we were on a wrong way and that it was necessary to change radically. Students were in class but they did not pay attention. Being an optative subject seemed necessary to adapt better the subject to student expectations maintaining basic contents and attaining subject targets. All it with the constraint of different levels of knowledge about Management Foundations including the possibility of some of them had only general ideas not necessarily true.

Original subject goal was to give a general kaleidoscope about innovation, technology management paying special attention to technological strategies and their link-up with the design. Detected the problem we asked permission to the master director to carry out a short evaluation of subject approach asking the students for bringing to light problem roots. At the beginning of next session, a short questionnaire about what they expected was filled joint to some questionnaires about creativity, Kolb learning style, group roles, active listening, etc. All that in order to know better student needs and characteristics.

\section{First edition deployment and results}

With a reduced syllabus and 22 hours left they had to take advantage for developing four tools applied on technology forecast: morphology. analogies, gap analysis and an adaptation of patent analysis for studying designs. These four tools were supported by techniques of spurring creativity and analysing ideas (de Bono, 2016, 2017a, 2017b, 2017c) (Gretz \& Dotzdeck, 1994) (Beebe \& Masterton,2014): brainstorming, de Bono hats, lateral thinking, nominal group and the five why?

This important challenge drove us to a different way of scheduling the class time looking for mixing theoretical elements with a design workshop. Session length was 4 hours divided on 
two parts. An initial theoretical part (60/90 minutes) and afterwards an atelier with the aim of applying new techniques, tools and concepts doing exercises or developing course project. Two hours left remained for preparing the project presentation three weeks after to finish the subject.

First problem consisted on defining group composition looking for attempting equilibrium among group roles in order to make easier attempting defined goals. To leave total freedom for trying group mates in our experience has revealed as not a good option in order to achieve desired results of efficacy and efficiency on group work. As far as each one of them had his Belbin profile the process was based on allowing students to choose group mates with the constraint of reaching an equilibrium among roles in the group. In this way was possible to develop transversal capacities linked to team work and decision making.

First year project was to design an innovative bicycle that could be utilized by ONG's on projects of aid in areas in need and sponsored by companied that could include advertising on the bicycles and a cost lower than $100 €$. Moreover, the design had to meet six conditions more:

- $\quad$ Easily adaptable to different sizes

- Easily adaptable to urban and extra-urban use.

- Maximum easy use and maintenance including extremely wet environments

- To have flat surfaces to be able to put publicity of project sponsors.

- $\quad$ Effective support for parking

- $\quad$ Capacity to carry cargo.

- Recyclable items as much as possible.

This project was an unexpected success with an output of five designs that went from a tricycle wit high cargo capacity and a sunshine for protecting the driver to a totally foldable set of bicycle and dragged cart for carrying cargo or people. But where innovation was more meaningful was on materials and their combination. For example:

- $\quad$ PVC bicycle frame.

- Gears replaced by PVC, or special plastics, disks.

- Transmission chain replaced by toothed belts.

- Bicycle wheels without radios. They were substituted by different designs of pvc designs.

- Some designs had a kind of cart, on the front or dragged, to carry cargo or people. On the case of the cart frame PVC, wood and even bamboo have been applied in 
Morphologic matrix application as a tool to spring on creativity. Results in a design master in the $U P V$

order to make a sustainable design. In the same way support area most common material was canvas but there were other kind of natural fibres.

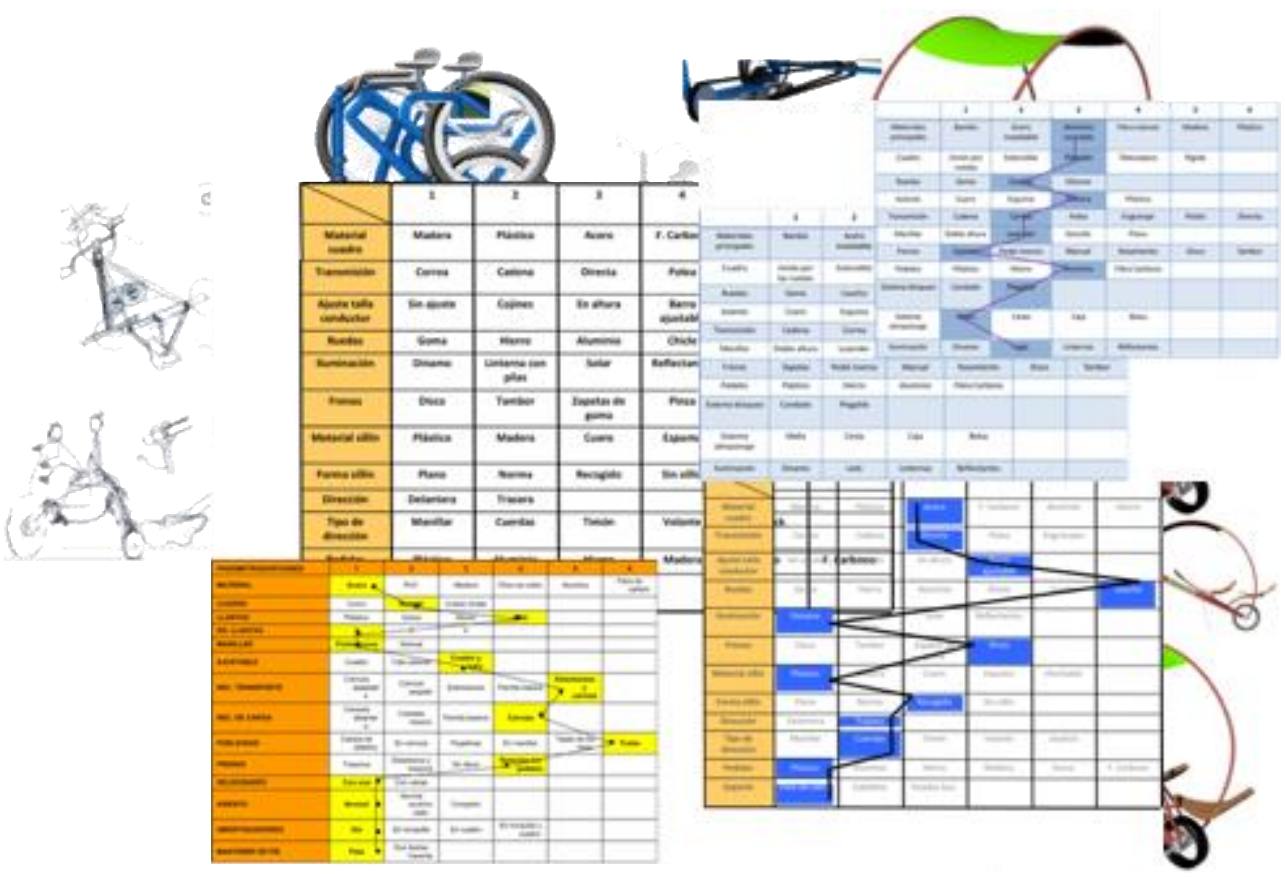

Figure 1. Morphologic matrices and some design ideas of first master edition

One advantage of this project was the possibility of calculating the efforts on the frame and to consider if different materials really could support them. This was one of the motives to utilize PVC of different thickness and diameter on the frame, since all the necessary information is available on internet joint to the variety of connection pieces and the possibility of cutting and gluing elements. 
Table 1. First edition results

\begin{tabular}{|c|c|c|c|c|c|c|}
\hline & $\begin{array}{c}\text { Strongly } \\
\text { agree }\end{array}$ & Agree & Neutral & Disagree & $\begin{array}{l}\text { Strongly } \\
\text { disagree }\end{array}$ & NA \\
\hline $\begin{array}{c}\text { Do you agree with the inclusion al final project in spite of the } \\
\text { number of extra hours at home it involves? }\end{array}$ & $83,87 \%$ & $12,90 \%$ & $0,00 \%$ & $0,00 \%$ & $0,00 \%$ & $3,23 \%$ \\
\hline $\begin{array}{l}\text { Do you consider this way of teaching the subject or you would } \\
\text { prefer the classic way? }\end{array}$ & $90,32 \%$ & $3,23 \%$ & $3,23 \%$ & $0,00 \%$ & $0,00 \%$ & $3,23 \%$ \\
\hline $\begin{array}{l}\text { Do you have considered interesting the two sessions on the } \\
\text { informatics aula for apllying Solid Works, Autocad and other tools } \\
\text { for performing final design? }\end{array}$ & $93,55 \%$ & $6,45 \%$ & $0,00 \%$ & $0,00 \%$ & $0,00 \%$ & $0,00 \%$ \\
\hline Do you consider correct final score you have attemped? & $77,42 \%$ & $9,68 \%$ & $9,68 \%$ & $0,00 \%$ & $0,00 \%$ & $3,23 \%$ \\
\hline $\begin{array}{l}\text { Do you agree with the three weeks for finising group project } \\
\text { before the public presentation? }\end{array}$ & $83,87 \%$ & $12,90 \%$ & $0,00 \%$ & $0,00 \%$ & $0,00 \%$ & $3,23 \%$ \\
\hline $\begin{array}{l}\text { Do you consider interesting the presentation essays and the } \\
\text { advices received for improving your project presentation? }\end{array}$ & $64,52 \%$ & $22,58 \%$ & $9,68 \%$ & $0,00 \%$ & $0,00 \%$ & $3,23 \%$ \\
\hline $\begin{array}{l}\text { Do you consider you have improved your capacities and abilities } \\
\text { for doing project presentations? }\end{array}$ & $74,19 \%$ & $9,68 \%$ & $9,68 \%$ & $0,00 \%$ & $0,00 \%$ & $6,45 \%$ \\
\hline \multicolumn{7}{|l|}{ Do yoy want to comment something? } \\
\hline & & & & & & \\
\hline & & & & & & \\
\hline & & & & & & \\
\hline & & & & & & \\
\hline & & & & & & \\
\hline & & & & & & \\
\hline
\end{tabular}

Really morphologic matrix was the main tool for groups in order to define the different elements and their possibilities. Gap analysis and analogies are tools for exploring the areas in which would were possibilities Morphology constitutes an interesting tool on forecasting over new products or new processes. It consists essentially on a matrix where all possible alternatives are systematically arranged. Matrix first vertical ordinate is a column of boxes corresponding to essential stages or parameters of technology under consideration. Each horizontal ordinate shows all known alternative methods of doing or achieving this essential stage. Linking an alternative of each stage it is possible defining a process way. Plotting current process alternative options for each stage give the possibility of new process ways. When a new technology appears, including when it is only an embryonic technology, it will be included making possible to imagine showing new possibilities with different combinations with other stages elements that could be the germ of an idea capable of generating an important change on the product or process, what could become an opportunity to the company,

Our university has a standardized questionnaire about student satisfaction but it does not provide enough information for improving the subject. So we usually design our specific questionnaires for each course or training activity. First year's results are gathered on Table 1. 

$U P V$

As it is possible to see changes were positive and finally student's satisfaction, despite to change subject schedule, was actually very high. Both the inclusion of the final project and the change of teaching were well received obtaining very high scores. What was possible perceive alongside the left classes was that new subject schedule was motivator since class assistance and participation grew highly and their behaviour was uniform until the end of class and tutorial sessions. Three points for improving next years were clearly: training on project presentations, to explain the scoring process for avoiding the feeling of not having received the right qualification, and to complete the syllabus for profiting all sessions.

\section{Problems tackled as final poject}

Logically each year it was necessary to purpose a new issue for developing the final project. Even some years there were the possibility of choosing between two different projects. Among other projects highlight:

- A box for sleeping in airports, that is already, used on some Asian countries, that can be rented by hours. The design had two main constraints: to dispose the necessary elements to spend the waiting time between flies comfortably. resting or working, and to be transported easily for maintenenace and change of place.

- A beach tricycle, or a similar vehicle, that would allow to be used by people with some disability considering three constraints: to allow them to move in an autonomous way near the shore, under surveillance, carrying the body into the water above the waist in order to enjoy the time on the beach; to be totally secure, and with the characteristic that up and down operations could be made over the beach sand where process ma be easier and made by several people; and finally to have a relative low cost that makes it profitable

- Multipurpose furniture for very small flats combining different elements and with the constraint of low cost.

- Diode lamps. In order to profit the new design possibilities than diode elements gave to designers the purpose was to apply this technology on any kind of lamp but with the constraint of the design made possible its manufacturing without problems, and indicating the manufacturing process on its main steps without details. 


\section{All editions student results}

Along six years more subject was teaching with different groups, totalizing more than one hundred students, maintaining the same schedule and trying to improve each year. Results are gathered on Table 2 .

Table 2. All edition results on average

\begin{tabular}{|c|c|c|c|c|c|c|}
\hline & $\begin{array}{c}\text { Strongly } \\
\text { agree }\end{array}$ & Agree & Neutral & Disagree & $\begin{array}{l}\text { Strongly } \\
\text { disagree }\end{array}$ & NA \\
\hline $\begin{array}{l}\text { Do you agree with the inclusion al final project in spite of the } \\
\text { number of extra hours at home it involves? }\end{array}$ & $81,31 \%$ & $7,48 \%$ & $6,54 \%$ & $0,00 \%$ & $0,00 \%$ & $4,67 \%$ \\
\hline $\begin{array}{l}\text { Do you consider this way of teaching the subject or you would } \\
\text { prefer the classic way? }\end{array}$ & $81,31 \%$ & $7,48 \%$ & $4,67 \%$ & $0,00 \%$ & $0,00 \%$ & $6,54 \%$ \\
\hline $\begin{array}{l}\text { Do you have considered interesting the two sessions on the } \\
\text { informatics aula for apllying Solid Works, Autocad and other tools } \\
\text { for performing final design? }\end{array}$ & $79,44 \%$ & $7,48 \%$ & $5,61 \%$ & $0,00 \%$ & $0,00 \%$ & $7,48 \%$ \\
\hline Do you consider correct final score you have attemped? & $73,83 \%$ & $10,28 \%$ & $7,48 \%$ & $4,67 \%$ & $0,00 \%$ & $3,74 \%$ \\
\hline $\begin{array}{l}\text { Do you agree with the three weeks for finising group project } \\
\text { before the public presentation? }\end{array}$ & $81,31 \%$ & $5,61 \%$ & $5,61 \%$ & $0,00 \%$ & $0,00 \%$ & $7,48 \%$ \\
\hline $\begin{array}{l}\text { Do you consider interesting the presentation essays and the } \\
\text { advices received for improving your project presentation? }\end{array}$ & $75,70 \%$ & $4,67 \%$ & $8,41 \%$ & $0,00 \%$ & $0,00 \%$ & $11,21 \%$ \\
\hline $\begin{array}{l}\text { Do you consider you have improved your capacities and abilities } \\
\text { for doing project presentations? }\end{array}$ & $74,77 \%$ & $9,35 \%$ & $9,35 \%$ & $1,87 \%$ & $0,00 \%$ & $4,67 \%$ \\
\hline \multicolumn{7}{|l|}{ Do yoy want to comment something? } \\
\hline & & & & & & \\
\hline & & & & & & \\
\hline & & & & & & \\
\hline & & & & & & \\
\hline & & & & & & \\
\hline & & & & & & \\
\hline
\end{tabular}

As it is possible to see on table 3 students thought, at the end of the subject, it had been useful and that the way of scheduling it ad been appropriate to what designers need to perform on their activity.

\section{Conclusions}

There are two main conclusions from this work. First one consists on before accept a challenge on a new area you don't know its very interesting to define a flexible schedule in order to adapt initial scheme reaching subject goals and actual needs of students. On second place to define a questionnaire different to each training activity is the better tool for improving continuously. Obviously always the institution as a standard questionnaire, but its goals are driven to know different elements about student's satisfaction, burt this is not enough for evolving and performing the training action. Moreover, is very important to highlight that to have on the trainer's group psychologists is a fundamental element since they give a different and complementary kaleidoscope of problems. 
Morphologic matrix application as a tool to spring on creativity. Results in a design master in the $U P V$

\section{References}

Beebe, A. \& Masterton, J. T, ,(2014) . Communicating in small groups. Principles and Practices. Pearson.

Belbin, M. (1993) . Team roles at work. Belbin Associates.

Chirstiansen, C.M.(1977) .The innovator's dilema. Harpper Business.

De Bono, E. (2010). Seis sombreros para pensar . Paidós Psicología.

De Bono, E. (2017). Creatividad. Paidós Psicología.

De Bono, E. (2017). El pensamiento lateral. Paidós Psicología.

De Bono, E. (2017). Seis pares de zapatos para la acción. Paidós Psicología.

Engleberg, I. \& Wynn, D. (2013) Working in groups. Pearson.

Escorsa, P. \& Maspons, R. (2001). De la vigilancia tecnológica a la inteligencia competitiva. Prentice Hall.

Figueroa, C. 1999. Creatividad, diseño y tecnología. Plaza y Valdés editores.

Gretz, K. \& Drozdeck, S. (1994). Aproveche la creatividad de sus empleados. Mc Graw Hill.

Jones, H. \& Twiss, B. (1980. Forecasting Technology for planning decisions.

Markridakis, S. \& Wheelwright, S. (1990). Forecasting Methods for Management. Willey.

Tidd. J., Bessant, J. \& Pavitt, K. (1960). Managing Innovation. Willey.

Williams,R. (2008). Diseño gráfico: fundamentos (diseño y creatividad). Anaya. 